ARTIKEL

\title{
DISINTEGRASI SOSIAL DALAM KONTEN MEDIA SOSIAL FACEBOOK
}

\author{
Lina Herlina \\ Program Studi Religious Studies \\ Program Pascasarjana UIN Sunan Gunung Djati Bandung \\ linaherlina386@gmail.com
}

\begin{abstract}
At first, social media came as a solution for the community to facilitate communication and interaction virtually. However, due to the absence of strict regulation, it later changed into a means to spread the utterances of hate in the form of certain terms. The term cannot be understood by everyone. Therefore, researchers tried to dismantle the terms used, namely in terms of meaning and also the ideology of the use of the term. As for the term utterance of hatred which is used as material for analysis, among them are the short axis people, the people of the flat earth, the people of napkins, the children of the tablecloths, the children of the lewd, the children of camels / camel urine, the people of the micin, the children of cebong, the children of the camps, and the children of the negligee. The analysis was carried out using Fairclough's theory namely the dimensions of the text, discourse practice and social practice. Meanwhile, to dismantle its ideology is by using the theory of Jagger and F. Maier which consists of context, output of text, means of rbetoric, content and ideological statements, peculiarities and positions of discourse.
\end{abstract}

Keywords: Hatespeech, Religious Intolerance, Sosial Media, Facebook

\begin{abstract}
Abstrak
Pada awalnya, media sosial hadir sebagai solusi bagi masyarakat untuk memudahkan komunikasi dan interaksi secara virtual. Akan tetapi karena tidak adanya regulasi yang ketat, kemudian berubah menjadi sarana untuk menyebarkan ujaran-ujaran kebencian dalam bentuk istilah-istilah tertentu. Istilah tersebut tidak dapat dipahami semua orang. Karenanya, peneliti berusaha membongkar istilahistilah yang digunakan yakni dari segi makna dan juga ideologi penggunaan istilah tersebut. Adapun istilah ujaran kebencian yang dijadikan bahan analisa diantaranya adalah kaum sumbu pendek, kaum bumi datar, kaum bani serbet, kaum bani taplak, kaum bani cabul, kaum bani onta/air kencing onta, kaum bani micin, kaum bani cebong, kaum bani kampret, dan kaum bani daster. Analisa dilakukan menggunakan teori Fairclough yakni dimensi text, discourse practice dan social practice. Sementara untuk membongkar ideologinya yakni dengan menggunakan teori Jagger and F. Maier yang terdiri dari konteks, luaran teks, sarana retorika, isi dan pernyataan ideologis, kekhasan dan posisi wacana.
\end{abstract}

Kata Kunci: Hatespeech, Intoleransi Keberagamaan, Media Sosial, Facebok. 


\section{A. Pendahuluan}

Pluralitas dalam kehidupan manusia merupakan suatu hal yang alami, wajar dan tak perlu dipermasalahkan. Kenyataan sosiologis adanya keberagaman ini juga harus dijunjung tinggi, dihormati, dan terus dipertahankan. Gerald O Collins dan Edward G. Farrugia mengungkapkan bahwa keberagaman ini melahirkan paham 'pluralisme' yakni pandangan filosofis yang tidak mediskripsikan segalanya pada prinsip, melainkan adanya penerimaan terhadap keragaman. Salah satu bentuk keberagaman yang terdapat di dunia ini adalah agama. Secara etimologi, Agama terdiri atas dua kata dari bahasa sansekerta yaitu A dan Gama. A berarti tidak dan Gama itu berarti kacau jadi agama adalah tidak kacau. Menurut Émile Durkheim dan Nasution, agama adalah suatu sistem terpadu yang terdiri atas kepercayaan dan praktik yang berhubungan dengan hal yang suci dan menyatukan semua penganutnya dalam suatu komunitas moral (umat).

Munculnya keberagaman agama di dunia seiring dengan kebutuhan manusia. Menurut Khotimah (2017) salah satu dari kebutuhan itu adalah kepentingan manusia dalam memenuhi hajat rohani yang bersifat spritual, yakni sesuatu yang dianggap mampu memberi motivasi semangat dan dorongan dalam kehidupan manusia. Sebelum ilmu pengetahuan berkembang, agama memegang peran penting dalam menjawab persoalan alam dan kehidupan manusia. Adanya beragam agama menunjukkan bahwa pendapat manusia tidak sama dalam melihat suatu masalah. Hosen Nasirdah (2005) menerangkan bahwa di Indonesia, agama yang diakui negara hanya 6 yakni Islam, Hindhu, Budha, Kristen, Katolik, dan Kong Hu Chu.

Indonesia terbentuk karena keberagamannya, termasuk juga karena keberagaman agamanya. 'Bhineka Tunggal Ika' walau berbeda tapi tetap satu jua' merupakan sebuah lambang negara yang merefleksikan keberagaman Indonesia yang bukan untuk dijadikan sebagai sekat melainkan perekat persaudaraan antar sesama. Negara juga menuangkannya kedalam konstitusi RI Undang-undang Dasar (UUD) 1945 dan Undang-undang (UU) No. 39 Tahun 1999 tentang Hak Asasi Manusia (UU HAM). Negara memberikan penghormatan, penghargaan dan jaminan kebebasan 
memeluk agama (kebebasan beragama) dan jaminan kebebasan menjalankan agama yang dipeluknya.

Kebebasan beragama yang dimaksud dalam undang-undang negara tersebut dinilai masih paradoksial. Pasalnya masih ada pembatasan tertentu yang dilakukan seperti ada pembatasan dalam jumlah agama yang di akui oleh negara serta pembatasan dalam praktek-nya. Sebagaimana dijelaskan diatas bahwa ada 6 agama saja yang diakui oleh negara. Sementara itu, dalam penerapan atau prakteknya, kegiatan beragama dan menjalankan praktek agamanya masih diatur oleh syarat dan ketentuan berlaku yakni yang tertuang dalam Undang-Undang yakni Pasal 28J ayat (2) UUD 1945 jo Pasal 73 UU HAM yang berbunyi sebagai berikut:

"Dalam menjalankan hak dan kebebasannya, setiap orang wajib tunduk kepada pembatasan yang ditetapkan dengan undang-undang dengan maksud sematamata untuk menjamin pengakuan serta penghormatan atas hak dan kebebasan orang lain dan untuk memenuhi tuntutan yang adil sesuai dengan pertimbangan moral, nilai-nilai agama, keamanan, dan ketertiban umum dalam satu masyarakat demokratis".

Adanya jaminan konstitusi kebebasan beragama dan pembatasan melalui syarat dan ketentuan berlaku tiada lain bertujuan untuk menumbuhkan sikap toleransi antar umat beragama. Dalam KBBI, toleransi berasal dari kata "toleran" yang artinya bersifat atau bersikap menenggang (menghargai, membiarkan, membolehkan), pendirian (pendapat, pandangan, kepercayaan, kebiasaan, dan sebagainya) yang berbeda dan atau yang bertentangan dengan pendiriannya. Sementara itu dari segi istilah, ada banyak sekali pendapat yang menyatakan tentang toleransi, salah satu diantaranya yakni menurut Umar Hasyim (1979) adalah sebagai berikut:

“Toleransi yaitu pemberian kebebasan kepada sesama manusia atau kepada sesama warga masyarakat untuk menjalankan keyakinannya atau mengatur hidupnya dan menentukan nasibnya masing-masing, selama dalam menjalankan dan menentukan sikapnya itu tidak melanggar dan tidak bertentangan dengan syaratsyarat atas terciptanya ketertiban dan perdamaian dalam masyarakat".

Toleransi atas kebebasan beragama tidak hanya diatur dalam undang-undang negara, namun juga sudah ada dalam ajaran agama masing-masing. Dalam Islam misalnya, ada ayat al-qur'an Laa Ikraha Fiddiin yang artinya 'Tidak ada paksaan untuk 
(memasuki) agama (Islam)' (QS. Al Baqarah: 256). Dalam ayat lain yakni Lakum Dinukum Waliyadin yang artinya 'Bagimu agamamu, dan bagiku agamaku' (QS. AlKafirun: 6). Selain itu, Ali bin Abi Thalib juga pernah berkata 'Dia yang bukan saudaramu dalam iman, adalah saudara dalam kemanusiaan'. Tidak hanya dalam alqur'an, dalam Al-kitab juga ada banyak ayat yang berbicara tentang toleransi seperti dalam Mat 5:43-44 - (43) 'Kamu telah mendengar firman: Kasihilah sesamamu manusia dan bencilah musuhmu. (44) Tetapi Aku berkata kepadamu: Kasihilah musuhmu dan berdoalah bagi mereka yang menganiaya kamu.' Lalu dalam piagam raja Asoka yang dianut Budha juga disebutkan bahwa 'Jangan membanggakan agamamu sendiri, jangan mencela agama orang. ....oleh sebab itu kerukunlah yang dianjurkan!'

Setiap agama menghendaki pemeluknya untuk menebar toleransi serta menjauhi sikap buruk sangka terhadap agama lain. Budaya toleransi dan komunikasi bertujuan untuk menciptakan kerukunan dalam kehidupan manusia. Fakhri Rizal (2017) mengungkapkan setidaknya ada tiga (tri) kerukunan umat beragama yang hendak dicapai / diraih yakni (1) kerukunan di intern umat beragama, (2) kerukan antar umat beragama, dan (3) kerukunan antar umat beragama dengan pemerintah. Akan tetapi pada kenyataannya, kerukunan umat beragama khususnya di Indonesia selama ini sering menghadapi masalah. Konflik atas nama agama sering menjadi salah satu persoalan pelik. Pada awal era reformasi, konflik antar umat beragama terjadi di Poso, Ambon, Mataram, dan tempat lain. Bahkan konflik tersebut melahirkan tragedi berdarah yang mencoreng kebhinekaan, kerukunan dan juga kemanusiaan. Ratnasari Hidayati (2017) mengungkapkan bahwa dalam konflik-konflik tersebut, infrastruktur agama memainkan peran dalam eskalasi konflik. Nilai-nilai agama sering diekplorasi sebagai alat untuk melegalkan suatu tindakan termasuk kekerasan.

Konflik berupa kekerasan fisik atas nama agama saat ini memang sudah tidak terjadi lagi tapi bukan berarti sikap tidak toleran (intoleransi) itu lenyap. Baru-baru ini sikap intoleran kembali mencuat dan banyak terjadi di sekitar kita. Salah satu yang dijadikan media kegiatan intoleran itu adalah 'media digital' salah-satunya media sosial. Di media sosial, semua orang bisa menuliskan, menyampaikan, mengkritik bahkan mencela dengan bebas tanpa ada batasan. Perkembangan media yang semakin terbuka tersebut tidak dibatasi dengan toleransi yang kuat untuk saling menghargai 
dan menghormati. Faktanya banyak hujatan, celaan dan bully-an yang dilakukan di media online tersebut. Salah-satu yang menarik perhatian adalah tentang hujatan yang menjurus dan menyudutkan antar kelompok beragama.

Hujatan-hujatan tersebut menyebar dalam beberapa media di internet seperti blog, forum, dan media sosial. Namun yang paling sering ditemui adalah di media sosial, hal ini mengingat karena media sosial menjadi platform paling banyak digunakan karena menjadi salah satu platform yang diciptakan untuk bersosialisasi secara digital. Ada banyak istilah-istilah hujatan yang muncul dan bahkan sempat 'viral' dan banyak digunakan untuk saling hujat dan saling serang di media sosial.

Fenomena saling hujat antar kelompok itu dilakukan dengan menggunakan beberapa istilah yang menyudutkan atau menyepelekan. Beberapa istilah yang ramai digunakan diantaranya adalah 'kaum sumbu pendek, kaum bani taplak, bani serbet, kaum bumi datar, air kencing onta,' dan banyak lagi istilah lainnya. Hujatan dengan istilah-istilah tersebut sebagian besar merujuk pada 'penyudutan' kelompok lebih jauhnya agama, bukan pada perseorangan. Tidak semua orang paham pada istilahistilah tersebut, hanya antar kelompok yang menggunakan istilah itu saja yang mengetahuinya. Akan tetapi hal itu bisa dipahami dengan cara membongkar makna dari istilah-istilah tersebut melalui konteks dalam status yang di posting oleh orangorang dari bagian kelompok tersebut.

Dari fenomena yang terjadi tersebut, peneliti tertarik untuk melakukan penelitian terhadap fenomena intoleransi dalam media digital khususnya di media sosial. Dalam penelitian ini, peneliti mengumpulkan istilah-istilah yang dihimpun dari media sosial facebook saja. Platform facebook dipilih karena pengguna facebook di Indonesia paling banyak dibandingkan user sosial media lainnya. Adapun istilah yang dipilih adalah istilah yang massif dan banyak digunakan. Selain itu, istilah-istilah tersebut juga sempat viral dikalangan user Facebook. Istilah-istilah yang diambil yakni hanya istilah yang bersentimen agama saja. Kemudian, istilah-istilah tersebut dianalisa menggunakan Analisis Wacana Kritis menurut Fairclough. Fairclough mengungkapkan bahwa untuk membongkar suatu makna dari kata, diperlukan 3 dimensi; (1) dimensi text, (2) discourse practice dan (3) social practice. Sementara untuk membongkar ideologinya yakni dengan menggunakan teori Jagger and F. 
Maier yang terdiri dari konteks, luaran teks, sarana retorika, isi dan pernyataan ideologis, kekhasan dan posisi wacana.

\section{B. Hasil dan Pembahasan}

\section{Toleransi dan Intoleransi Beragama}

Istilah toleransi muncul beriringan dengan adanya konsep pluralisme. Segala yang ada di bumi ini bersifat plural (beranekaragam). Manusia dari segi fisik memang hanya ada dua yakni pria dan wanita, namun dari segi lain sangatlah beragam termasuk keyakinan dan kepercayaan mereka. Rustin Armala (2011) mengungkapkan bahwa keberagaman tersebut di satu sisi bisa menjadi daya penyatu (sentripental) buktinya Indonesia merdeka diatas keragaman. Namun disisi lain, keberagaman ini bisa berdampak negatif berupa daya pemecah (sentrifugal).

Toleransi dalam beragama kini menjadi tema penting yang banyak diperbincangkan. Masih terdapat pro -kontra mengenai konsep, penerapan dan batasan toleransi ini. Djohan Effendi (2009) menjabarkan bahwa kata "toleransi" berasal dari bahasa Latin yakni toleran, yang artinya membiarkan mereka yang berpikiran lain atau berpandangan lain tanpa dihalang-halangi. Sementara itu, menurut Abdullah bin Nuh (1995) dalam bahasa Arab, Toleransi diartikan dengan ikhtimal, tasyaamuh yang artinya sikap membiarkan dan lapang dada. Jadi, dapat dipahami bahwa toleransi berarti kelapangan dada dan rukun, membiarkan orang lain berpendapat atau berpendirian lain, tidak mau mengganggu kebebasan berpikir ataupun berkeyakinan lain. Namun hal-hal tersebut tentu ada batasan dan aturan yang berlaku dan harus dipatuhi. Batasan yang selama ini biasa digunakan adalah selama tidak melanggar dan tidak bertentangan dengan syarat-syarat azas terciptanya perdamaian dalam masyarakat.

Dalam Episteme (2009) Toleransi adalah istilah dalam konteks sosial, budaya dan agama yang berarti sikap dan perbuatan yang melarang adanya diskriminasi terhadap kelompok-kelompok yang berbeda atau tidak dapat diterima oleh mayoritas dalam suatu masyarakat mengizinkan keberadaan agama-agama lainnya. Dalam beragama, toleransi bisa didefinisikan sebagai upaya untuk menghargai dan menghormati segala yang menjadi hak beragama masing-masing. Dengan kata lain, Toleransi Beragama merupakan sebuah realisasi dari ekspresi keagamaan dalam bentuk komunitas. Menurut Joachim Wach (1958), ada 3 dimensi yang 
mempengaruhi keberagamaan seseorang, yang pertama yaitu doktrin, yang kedua adalah ritus, dan yang terakhir adalah institusi/lingkungan. Dengan demikian, sikap toleransi beragama merupakan realisasi dari religiusitas yang matang untuk menjaga kerukunan antar sesama manusia dalam bentuk jalinan sosial antar umat beragama dan juga dalam lingkup intern agama.

Toleransi beragama sangat penting karena merupakan akomodasi dalam lingkup interaksi sosial. Manusia beragama maupun ateis sejatinya tidak dapat menafikan keharusan untuk bergaul dan bersosialisasi karena saling membutuhkan dalam perihal muamalah ataupun lain-lain. Kebutuhan tersebut, tidak hanya meliputi dengan kelompoknya sendiri melainkan dengan kelompok yang berbeda agama. Umat beragama dituntut selalu mempunyai sikap toleransi karena untuk menjaga kestabilan sistem sosial masyarakat sehingga benturan ideologi dan konflik dapat terhindarkan. Dengan begitu, tiap-tiap umat beragama berkewajiban menahan diri, sehingga diharapkan tidak menyinggung perasaan umat agama lain. Hal ini akan membawa kehidupan masyarakat dalam kerukunan tanpa ada pihak-pihak yang merasa tersudutkan.

Bashori Mulyono (2010) mengungkapkan bahwa dengan toleransi dan kerukunan ini diharapkan dapat terwujud ketenangan, saling menghargai ketertiban dan keaktifan menjalankan ibadah menurut agama dan keyakinannya masing-masing. Toleransi terhadap keragaman mengandung pengertian bahwa setiap orang harus mampu melihat perbedaan pada diri orang lain atau kelompok lain sebagai sesuatu yang tidak perlu dipertentangkan. Pertentangan bukan hanya melukai hubungan antar agama namun juga perihal kemanusiaan.

Keragaman beragama dalam segala segi kehidupan merupakan realitas yang tidak mungkin untuk dihindari. Namun, dalam keragaman tersebut seringkali tersimpan juga potensi destruktif yang meresahkan. Di era ini, keragaman dan kemajemukan masyarakat cenderung menjadi beban terbukti dari munculnya berbagai masalah yang sumbernya berbau kemajemukan, khususnya bidang agama.

Potensi intoleransi beragam terkadang berakar pada ajaran masing-masing. Setiap pemeluk agama akan memandang benar agama yang dipeluknya. Ketika mereka terlalu fanatik, akan ada indikasi untuk memaksakan suatu agama terhadap orang yang sudah beragama. Karenanya munculah sikap intoleransi yakni sikap untuk 
ARTIKEL

tidak menerima keberagaman dan cenderung memaksakan prinsip-nya kepada orang lain. Munandar (1987) menegaskan bahwa perpecahan dalam suatu kelompok akan timbul jika terdapat penolakan terhadap pandangan hidup lama atau yang berbeda dalam hal agama. Padahal dalam satu agama-pun terdapat pluralitas internal, baik berkenaan dengan aspek penafsiran maupun aspek pelembagaanya.

Tindakan intoleransi dalam kehidupan beragama sering menimbulkan teror di masyarakat. Dengan berdalih pada agama seseorang atau sekelompok orang melakukan kekerasan terhadap orang lain sehingga orang lain atau kelompok merasa takut atau terancam hidupnya. Tindakan intoleransi sering mengarah pada radikalisme. Radikalisme adalah paham atau aliran yang menginginkan perubahan atau pembaharuan sosial dan politik dengan cara kekerasan atau drastic (KBBI Online). Mereka yang memiliki paham radikal biasanya memiliki penafsiran yang fundamental terhadap ayat suci yang dipedomaninya yang akan rela melakukan apa saja demi membela agamanya. Mereka yang punya pemahaman radikal sering di hubungkan dengan aliran fundamentalisme.

Radikalisme masuk dalam kategori intoleransi dan biasanya dihubungkan dengan Islam. Beberapa media orientalist seringkali mencoba menjadikan isu radikalisme ini sebagai alat untuk menyudutkan Islam, seolah orang-orang Islam tidak toleran. Akan tetapi pada kenyataannya tidak hanya orang-orang Islam saja yang berlaku intoleran namun juga dari kalangan agama lain. Hal itu terlihat jelas dalam fakta kasus hujatan-hujatan (saling hujat) di media digital seperti sosial media.

\section{Pola Intoleransi Beragama dalam Media Digital}

Kemunculan internet telah merubah segalanya mulai dari cara hidup sampai cara berpikir. Kini semua orang bisa mempublikasikan pemikirannya di ranah publik dengan hanya memposting status di media sosial. Di satu sisi, keberadaan media ini bisa membantu untuk hal-hal positif kemajuan manusia. Namun disisi lain bisa memberikan dampak negatif yakni perihal kebebasan yang tak berbatas. Semua orang bisa dengan bebas mempublikasikan apa saja yang ada di pikiran mereka baik itu pendapat, kritik bahkan sampai pada hujatan dan juga hinaan. Adapun hal atau tema yang dipublikasikan juga sangat beragam mulai dari kegiatan sehari-hari, politik, budaya, dan bahkan agama. 
ARTIKEL

Fathur Rohman (2016) dari hasil penelitiannya menemukan bahwa kasus hujatan intensitasnya meningkat menjelang Pemilihan Kepala Daerah (Pilkada). Pilkada adalah pertarungan politik. Politik adalah tentang bagaimana cara memenangkan persaingan. Ironisnya untuk mendapatkan apa yang dia inginkan dan memenangkan persaingan, banyak yang rela melakukan apa saja sampai mengabaikan etika dan perikemanusiaan. Ada banyak alat juga yang digunakan untuk memenangkan persaingan salah satunya adalah agama. Faktanya, agama sering dijadikan alat untuk melanggengkan kekuasaan dan kepentingan suatu kelompok.

Fenomena intoleransi di Indonesia mencuat menjelang pilkada Jakarta tahun 2016 lalu. Umat Islam menghendaki pemimpin Jakarta yang beragama Islam. Hal itu tentu dipahami oleh agama lain sebagai salah satu bentuk diskriminasi dan bahkan intoleransi. Karena setiap agama memandang agamanya yang paling benar, maka kemudian masing-masing agama memegang kuat prinsipnya. Sebagian besar umat Islam menafsirkan ayat-ayat yang ada dalam al-Qur'an tentang keharusan memilih pemimpin dari kalangan muslim dan tak boleh memilih pemimpin no-mulim (kafir). Ayat-ayat yang dimaksud diantaranya:

"Janganlah orang-orang mukmin mengambil orang-orang kafir menjadi wali dengan meninggalkan orang-orang mukmin. Barang siapa berbuat demikian, niscaya lepaslah ia dari pertolongan Allah, kecuali karena (siasat) memelihara diri dari sesuatu yang ditakuti dari mereka. Dan Allah memperingatkan kamu terhadap diri (siksa)-Nya. Dan hanya kepada Allah kembali(mu)." (QS: Ali 'Imraan: 28).

Selain ayat diatas, banyak juga ayat lain yang berhubungan seperti An-Nisaa': 144, Al-Maidah: 51, Al-Maa-idah: 57 dan ayat serta hadis lain. Sementara non-muslim menginginkan agar pemilihan pemimpin dilakukan dengan tidak membawa-bawa agama. Karena masing-masing ingin memenangkan pilihannya, maka terjadilah konflik. Bahkan konflik yang terjadi bukan hanya antara muslim vs non-muslim namun juga muslim vs muslim sendiri. Sesama muslim juga ternyata terjadi perbedaan pendapat serta penafsiran terhadap ayat-ayat yang berbicara tentang pemilihan pemimpin tersebut. Akhirnya hal ini memecah umat muslim itu sendiri bahkan bukan hanya di jakarta namun juga di indonesia.

Konflik yang terjadi bukan kekerasan fisik namun kekerasan dalam bentuk pendapat, opini dan hujatan (batespeech) dalam media digital. Di media sosial misalnya, 
ARTIKEL

ada banyak ditemukan posting-posting yang bernada hujatan. Pola hujatannya adalah dalam bentuk saling serang antar kelompok yang lebih jauh sebetulnya mengarah pada agama yang dianut oleh masing-masing.

\section{Teks Hujatan di Medsos}

Teks itu meliputi tidak hanya yang dilisankan dan ditulis, tetapi termasuk pula kejadian-kejadian yang nirkata (non-verbal) lainnya - keseluruhan lingkungan teks itu (Halliday, 1994). Lalu seiring dengan perkembangan teknologi tulisan tidak hanya bisa dibuat atau dituangkan dalam sebuah kertas namun kini bisa dituangkan dalam versi virtual. Adanya Teknologi Microsoft Office, itu memungkinkan seseorang menulis dalam lembar dokumen secara digital yang kemudian bisa dicetak kedalam versi hardcopy. Kemudian teks atau tulisan juga tidak hanya ditulis untuk kebutuhan cetak saja namun juga untuk dipublikasikan secara digital.

Kemunculan teknologi Hyper Text Markup Language (HTML) memungkinkan siapa saja mempublikasikan tulisannya dalam page khusus yang kemudian disebut dengan website. Era sekarang, orang-orang dapat mempublikasikan tulisannya dalam media sosial lewat akun pribadi yang dimilikinya yang kemudian secara berjejaring bisa dilihat oleh banyak orang secara publik. Setiap ada perkembangan teknologi, seringkali hal itu bersifat paradoksial. Hal ini karena di satu sisi memberikan pengaruh positif namun di sisi lain selalu ada celah untuk pengaruh negatif. Salah satu diantaranya adalah adanya kasus hujatan di media sosial yang menjadi fokus kajian dari penelitian ini.

Orang-orang bisa dengan bebas untuk menulis dan mempublikasikan apa saja baik itu berupa pendapat, kritik bahkan juga hujatan di media sosial tersebut. Perihal teks hujatan tersebut, ada banyak hasil penelitian yang menunjukan bahwa saat ini media sosial dipenuhi dengan teks-teks hujatan. Seperti penelitian tim tirto.id, setidaknya ada 90ribu/bulan akun yang memposting hujatan di social media.

Teks-teks hujatan tersebut tentu bisa dianalisa menggunakan teori Critical discourse analysis. CDA atau Analisis Wacana kritis membantu memahami bahasa dalam penggunaannya. Kini bahasa bukan sekedar menjadi alat komunikasi, melainkan juga digunakan sebagai instrumen untuk melakukan sesuatu atau sarana menerapkan strategi kekuasaan. Kemampuan memahami fungsi bahasa membuat 
lebih jeli dalam memperhitungkan konsekuensinya sehingga mampu meningkatkan efektivitas komunikasi dan strategi wacana. Bahasa berfungsi sebagai alat identifikasi dan sarana kontrol sosial. Itulah sebabnya mengapa bahasa menjadi pra syarat untuk mengembangkan praktik dan persetujuan sosial. Analisis Wacana Kritis (AWK) diaplikasikan agar dapat membongkar apa yang salah atau tidak beres dalam masyarakat; ketidakadilan, ketidaksetaraan, pembatasan kebebasan atau perihal diskriminasi.

Pendekatan seperti ini membantu untuk membongkar hubungan ideologi dan bahasa dalam suatu teks. Objeknya yakni semua sumber data yang berupa dokumen, kertas diskusi, perdebatan, pidato, kartun, iklan, foto, Koran atau sumber media lain, maka risalah politik, film dan juga famplet dapat dianalis dengan AWK ini. Pendekatan baru ini membuka perspektif luas untuk memecahkan masalah ketidakadilan, dominasi dan diskriminasi yang tengah terjadi dikalangan masyarakat. Menurut Deborah Schiffrin (2007), analisis wacana kritis juga dapat diartikan sebagai suatu kajian yang meneliti atau menganalisis bahasa yang digunakan secara alamiah, baik dalam bentuk tulis maupun lisan terhadap para pengguna sebagai suatu elemen masyrakat. Pada prakteknya, kajian wacana ini dilakukan secara struktural dengan menghubungkan antara teks dan konteks. Selain itu, proses analisa juga dilihat dengan menganalisis tindakan yang dilakukan seseorang dengan tujuan tertentu untuk memberikan makna kepada partisipan yang terlibat.

AWK bertujuan untuk menganalisis bagaimana wacana memproduksi dominasi social, mendorong penyalahgunaan kekuasaan suatu kelompok terhadap kelompok yang lain dan juga bagaimana kelompok yang didominasi melalui wacana melawan penyalahgunaan tersebut. Ada banyak teori discourse yang selama ini populer dan banyak digunakan. Namun salah satu yang paling dianggap relevan dengan penelitian ini adalah teorinya Norman Fairclough. Fairclough (1995) mengusung model 3 dimensi dalam menganalisa sebuah tulisan. Ketiga dimensi yang dimaksud adalah (1) teks (tuturan, pencitraan visual atau gabungan ketiganya) (deskripsi), (2) praktik wacana yang melibatkan pemproduksian dan pengkonsumsian teks, (interpretasi) (3) praktik sosial, (eksplanasi).

Teks hujatan yang didapatkan lewat pengumpulan data dari media sosial tersebut akan dianalisa dengan menggunakan teori Fairclough tersebut. Tujuan 
utamanya adalah untuk mengetahui makna dari hujatan-hujatan yang tengah terjadi di media sosial terutama platform facebook. Selain itu, dengan penggunaan teori Fairclough ini diharapkan dapat membongkar ideologi yang tersembungi dalam teks hujatan tersebut. Setelah ideologinya terbongkar, maka akan dihubungkan dengan fenomena intoleransi beragama. Fenomena intoleransi beragama tersebut menjadi fokus perhatian penting yang sesuai dengan tema dari penelitian ini. Analisa intoleransi beragama difokuskan untuk dianalisa dalam social practice.

\section{Faktor Penyebab Munculnya Istilah Hujatan}

Fenomena munculnya istilah hujatan di media digital disebabkan oleh beberapa hal. Ada dua masalah utama yakni pertama adalah karena kurang bijaknya masyarakat dalam mengikuti perkembangan teknologi. Kedua karena kurangnya filter dari platform digital tersebut. Dari proses observasi yang dilakukan, peneliti menemukan banyak media digital khususnya media sosial yang sudah terkontaminasi hujatan-hujatan intoleran. Facebook adalah salah satu diantaranya yang kontennya mengandung beragam hujatan dan sudah masuk ke ranah hatespeech.

Berdasarkan survey yang dilakukan oleh Social Progress Index dari periode 2014 2017, skor toleransi beragama di Indonesia ada pada titik terendah yakni sebesar 2,0. Data tersebut bisa dilihat dalam data berikut ini:

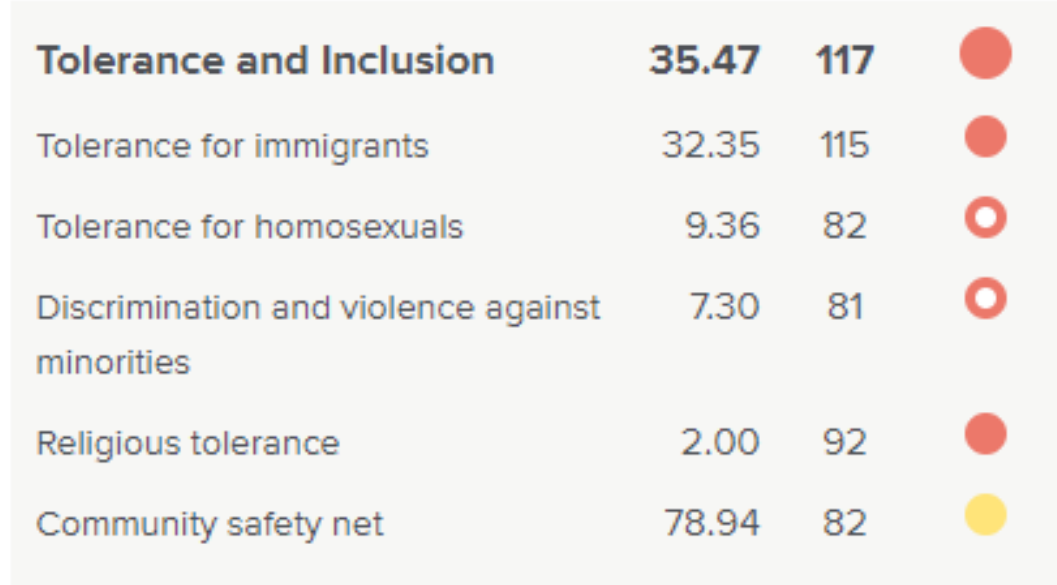

(Data Tolerance and Inclusion di Indonesia; socialprogressindex.com)

Periode tersebut merupakan tahun politik di Indonesia. Bahkan di 2016 terjadi konflik politik terkait kampanye pemilu pilkada serentak 2017 DKI Jakarta. 
Selama ini pertarungan pemilu seringkali menggunakan isu identitas untuk kampanye, mobilisasi massa, dan menjatuhkan lawan politik. Menguatnya isu identitas suku, agama, ras menjadi salah satu faktor meningkatnya situasi intoleran di Indonesia.

Dengan adanya fenomena tersebut, kemudian menurut Scholastica Gerintya (2018), intoleransi menjadi sangat erat hubungannya dengan demokrasi. Penilaian tingkat toleransi dan intoleransi sebuah negara sering dinilai juga dari kondisi demokrasinya. Dengan kata lain, unsur toleran dan tidak toleran termasuk dalam penilaian bagaimana situasi politik dan demokrasi di suatu negara dilihat. Hal itu bisa dilihat juga dari data laporan Democracy Index dari The Economist Intelligence Unit. Berdasarkan laporan tersebut, indeks demokrasi di Indonesia memperlihatkan tren menurun dari 2014-2017.

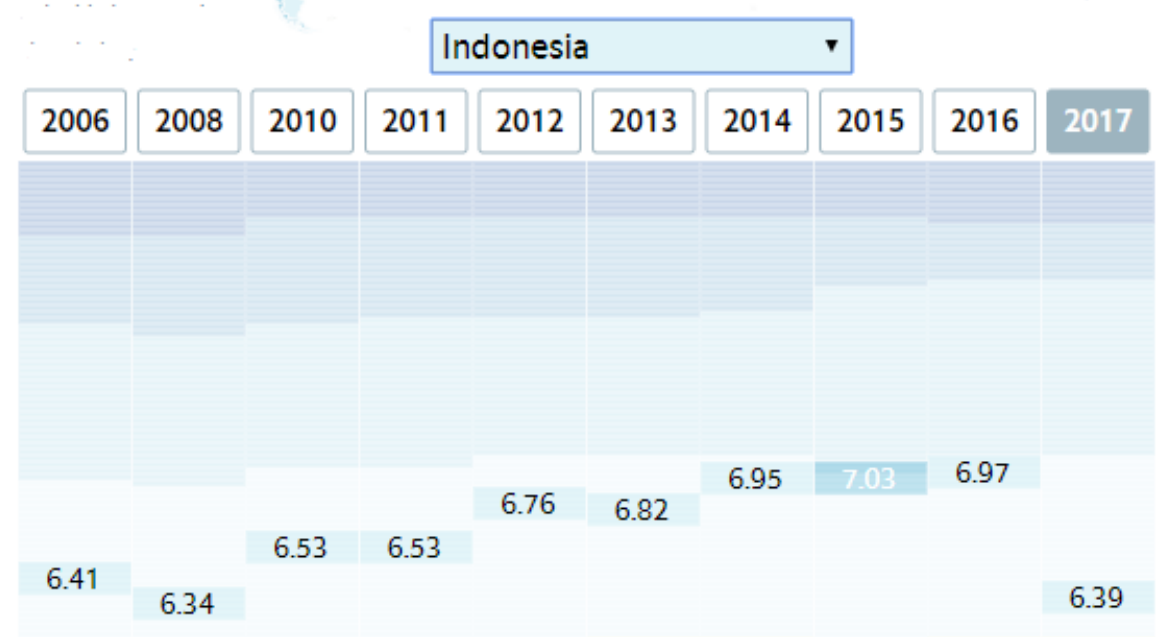

(Data Democracy Index Indonesia; http:// infographics.economist.com/2018/DemocracyIndex)

Fenomena intoleransi di Indonesia mencuat menjelang pilkada Jakarta tahun 2016 lalu. Umat Islam menghendaki pemimpin Jakarta harus beragama Islam. Hal itu dipahami oleh agama lain sebagai salah satu bentuk diskriminasi dan bahkan intoleransi. Karena setiap agama memandang agamanya yang paling benar, maka kemudian masing-masing agama memegang kuat prinsifnya. Karena masing-masing ingin memenangkan pilihannya, maka terjadilah konflik. Konflik yang terjadi di media sosial selama ini adalah adanya pihak yang menjagokan pilihannya dan lupa akan kekurangan serta tidak mau calon-nya dikritik. Sebaliknya masyarakat yang mendukung calon lain, juga memiliki anggapan yang sama. 
Tak dipungkiri jika pilkada menghasilkan masyarakat yang terbelah. Bukan hanya pada saat menjelang pilkada akan tetapi setelah itu bahkan sampai pemilihan lima tahun mendatang kembali lagi. Masyarakat yang calonnya tidak lolos seringkali tak bisa menerima dan berlarut-larut dalam sakit hati. Mereka tidak bisa menerima calon yang lolos terpilih menjadi pemimpin. Apalagi jika kebijakan dari pemimpin yang mereka pilih itu tidak sesuai dengan harapan rakyat. Mereka akan mengkritisi pemimpin itu dan bahkan sampai menyalahkan kelompok lain yang dahulu mendukungnya.

Bukti riil bisa dilihat dari hasil pilkada Jakarta kemarin yang telah menyisakan dendam khususnya dari kelompok yang calon-nya tidak menang dalam pemilihan. Pilkada kemarin merupakan bagian dari konflik beragama karena Islam menyatakan untuk mendukung pemimpin yang beragam Islam dan melarang umat untuk memilih pemimpin yang non-muslim (kafir). Hal ini dipandang dan dianggap sebagai salah satu tindakan yang tidak toleran oleh non-Islam. Non-Islam merasa bahwa mereka memiliki hak dan kewajiban untuk menjadi pemimpin di negara dengan sistem pancasila ini. Mereka tidak terima jika hak asasi mereka dijegal bukan secara konstitusi melainkan secara politis.

Luka non-muslim semakin menjadi ketika ada beragam kegiatan kampanye yang bukan hanya menyudutkan mereka sebagai non-muslim, namun juga menyudutkan ras-ras tertentu seperti china, tionghoa dan lain sebaginya. Maka dari itu, selama masa kepemimpinan gubernur baru Jakarta Anis Baswedan, beragam upaya untuk menyudutkan gubernur dan para pendukungnya sering terjadi dan banyak fakta yang bisa ditemukan. Salah-satu contohnya yakni adanya sebutan 'gabener' sebagai plesetan dari 'gubernur'. Kemudian ada juga beberapa ungkapan lain seperti ditulis dalam status 'nih hasil kerjaan gubernur yang seiman' sambil memperlihatkan keburukan kinerja dari gubernur baru. Pendukung gubernur Anis yang sebagian besar adalah muslim tentu berusaha untuk membela dan tak sedikit juga dari mereka yang menghina seperti dengan sebutan 'cebong, ahoker, dll' dengan sadis pula. Tentu ini akan memperkeruh suasana dimana memperdalam luka bagi non-muslim yang merasa mendapatkan perlakukan intoleran tersebut.

Dalam proses kampanye Pilkada DKI Jakarta, konflik bersentimen agama terjadi dan terlihat jelas. Demo besar-besaran dilakukan kelompok muslim menuntut 
Basuki Tjahja Purnama (Ahok) untuk diadili karena kasus penghinaan agama. Hal itu terjadi bertepatan dengan momen kampanye politik sehingga ada kelompok yang menduga jika demo-demo tersebut adalah salah-satu bentuk upaya menjatuhkan lawan politik. Padahal sebetulnya demo tersebut hanya menuntut keadilan (justice) dari penegakan hukum di Indonesia. Dalam hal ini pertentangan political structure terjadi antara pandangan Islam yang menganggap penegakan hukum yang tak segera dilakukan, serta kaum pendukung ahok yang menganggap kaum Islam yang demo tidak taat pada menunggu proses hukum dan menilai aksi tersebut dimaksudkan untuk menekan pihak berwajib segera menangkap Ahok.

Hal ini senada dengan penelitian M Taufiq Rahman (2014, 282) yang membandingkan pemikiran Rawls dan Qutb. Lebih jauh membandingkan struktur politik Islam dan juga barat (west). Rawls menegaskan pentingnya menghormati constitutional democracy. Sementara Qutb yang menjadi representasi Islam menyebutkan bahwa "Democracy or not is not Qut's business. For him the important thing is to uphold justice". Umat Islam yang demo hanya menuntut keadilan saja, namun persepsi dari nonmuslim atau muslim yang mendukung Ahok berbeda.

Kecurigaan dan dugaan non-muslim kepada muslim bukan tanpa alasan. Ada banyak fakta dan data, bahkan adanya fatwa yang mengharuskan memilih pemimpin muslim, itu menjadikan kelompok non muslim khususnya merasa didiskriminasi. Akhirnya peperangan non fisik-pun terjadi, khususnya yang ada di media sosial seperti facebook.

Kemudian peneliti menemukan fenomena 'perang' tersebut terjadi lebih besar di media sosial salah satunya facebook. Akan tetapi ada hal unik dari perang opini tersebut yakni adanya julukan-julukan yang digunakan dengan tujuan untuk menjatuhkan lawan. Parahnya lagi, sebagian besar diantaranya membawa sentimen agama. Beberapa julukan atau hujatan batespeech yang digunakan di media sosial sangat banyak sekali, diantaranya adalah

1. Kaum bumi datar,

2. Kaum sumbu pendek,

3. Kaum bani taplak,

4. Kaum bani serbet,

5. Kaum bani cebong, 

6. Kaum bani kampret,
7. Kaum bani cabul,
8. Kaum bani onta,
9. Kaum bani micin
10. Kaum bani daster.

\section{Makna Istilah Hujatan Media Sosial Facebook}

Penggunaan istilah hujatan yang unik tersebut terkadang tidak bisa dipahami secara literal, diperlukan analisa kontekstual dan interpretasi sosial untuk itu. Peneliti menggunakan teori Fairclough untuk membedah makna tersebut dari tiga dimensi berbeda yakni dimensi text, dimensi discourse practice dan social practice. Peneliti menemukan beberapa fakta tentang penggunaan istilah tersebut.

Dari 10 istilah yang dianalisa, peneliti menemukan bahwa semuanya tidak bisa dipahami jika hanya diartikan dari segi leksikal atau literal saja. Untuk bisa memahami maksud tersebut dibutuhkan pemahaman lebih secara konteks dan interpretasi. Kemudian peneliti menemukan beberapa makna yang dimaksud dari penggunaan istilah julukan hatespeech antar kelompok tersebut. Adapun Status-status yang diambil menjadi contoh dibawah ini adalah Istilah yang paling banyak digunakan oleh para user facebook untuk saling serang antar kelompok dengan memuat dan mengandung sentimen agama dari tahun 2016 sampai dengan sekarang.

a) Kaum Bumi Datar (Mencapai 549.000 result sejak tahun 2016)

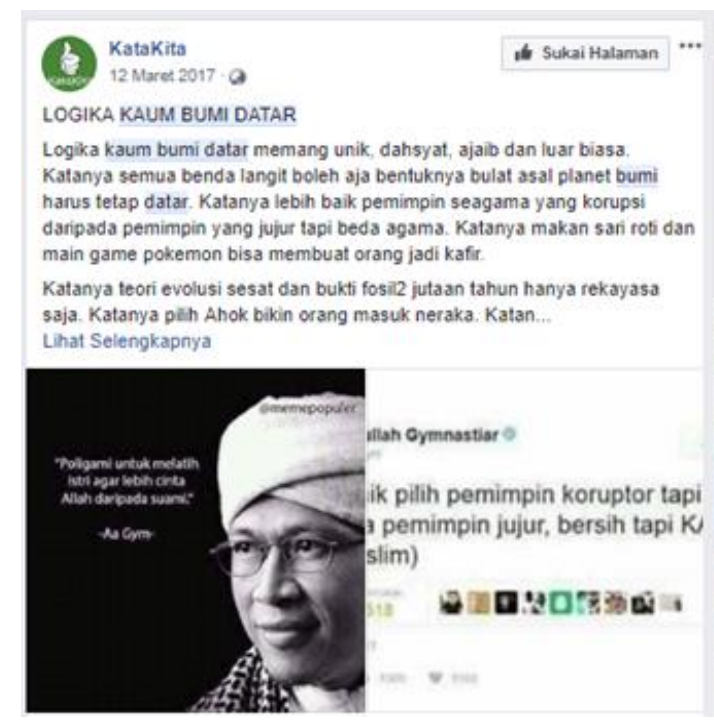 18. Denny Siregar membagikan foto.
Karena sudah terlalu banyak kaum bumi datar di page, saya akan memberikan analisa tentang NKRI di page Joko Widodo sebagai surat terbuka dan semoga bisa dibaca beliau.
Saya cinta negeri tempat saya dillahirkan, karena itu kegelisahan saya harus terus disalurkan

Kalau biak keberatan, silahkan di like pagenya.

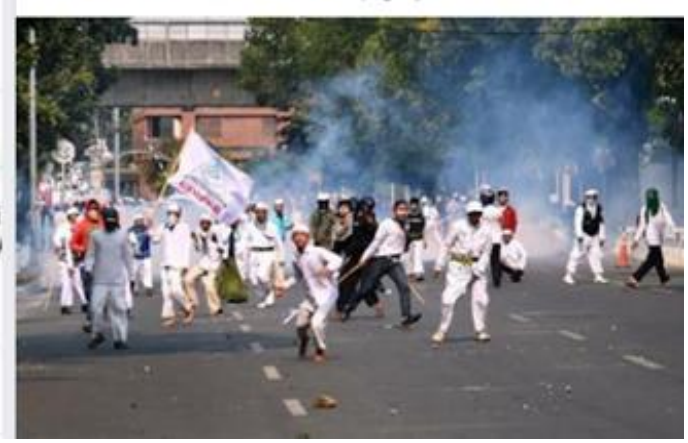


Dalam bukti ScreenShot diatas, ditemukan bahwa kaum bumi datar memiliki makna sebagai kelompok orang yang memiliki kesamaan dengan flat earth society yakni sebuah penganut yang percaya bahwa bumi itu datar padahal sudah banyak fakta ilmiah yang mengungkap jika bumi itu bulat. Ini disematkan pada kelompok yang ngeyel, dogmatis, dan tidak rasionalis.

b) Kaum Sumbu Pendek (Mencapai 120.000 result sejak tahun 2016)

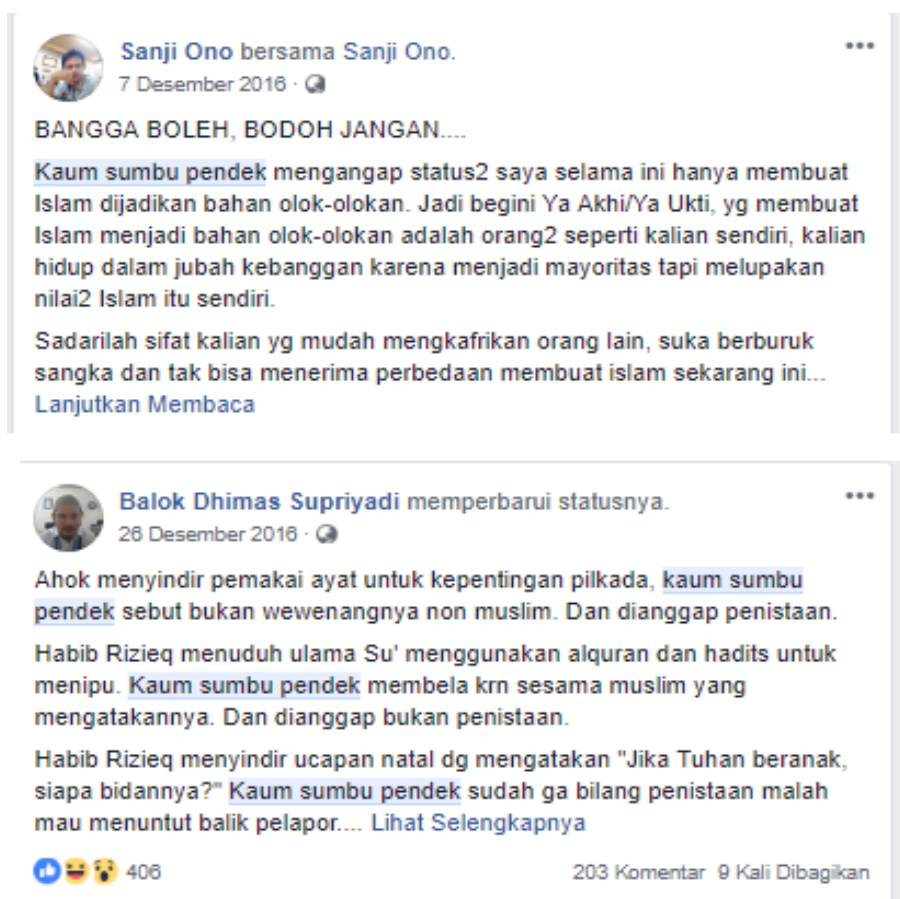

Interpretasi yang diperoleh dari status tersebut adalah bahwa kaum sumbu pendek memiliki makna sebagai kaum yang mudah tersulut emosi, bahkan untuk halhal yang belum jelas. Ini pada awalnya disematkan untuk kelompok yang suka dan selalu melakukan demontrasi.

c) Kaum Bani Taplak (Sebanyak 6.500 result sejak tahun 2017) 
ARTIKEL

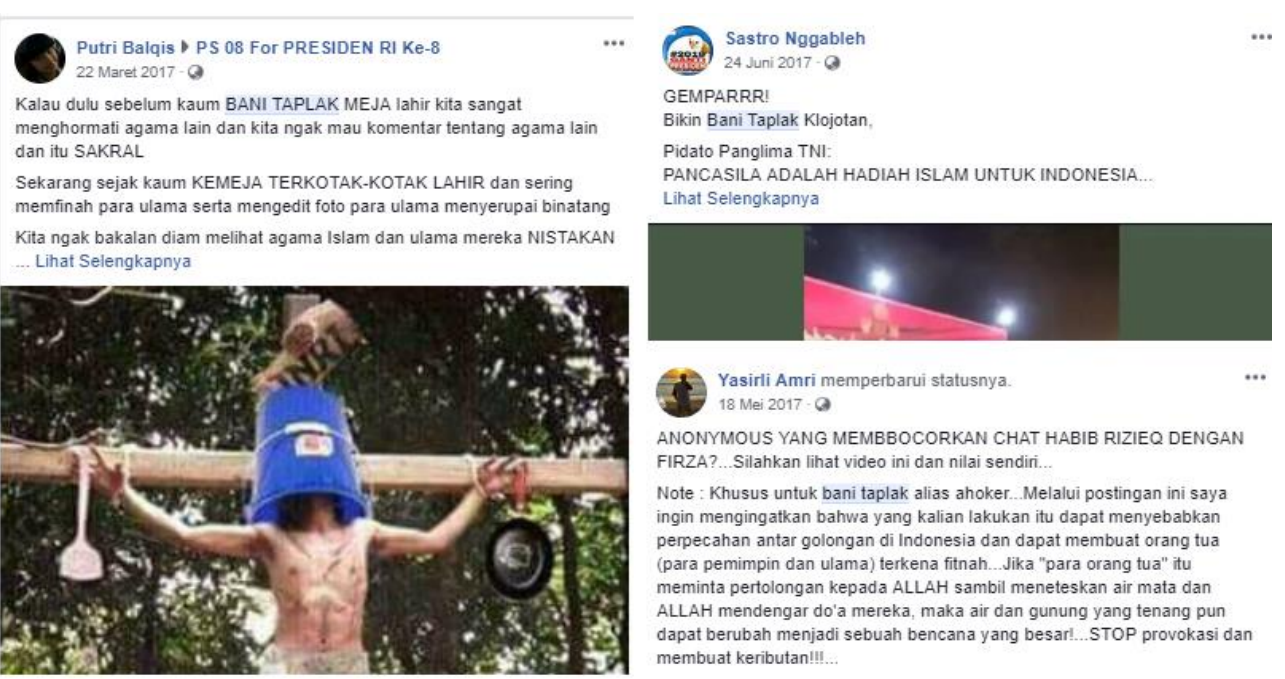

Makna yang terdapat pada status user facebook tersebut jelas menunjukan bahwa kaum bani taplak memiliki makna bahwa kelompok dengan julukan ini merupakan pendukung Ahok atau Jokowi. Itu karena pada saat kampanye Jokowi dan Ahok menggunakan baju kotak-kotak.

d) Kaum Bani Serbet (Sebanyak 12.800 result sejak tahun 2017)

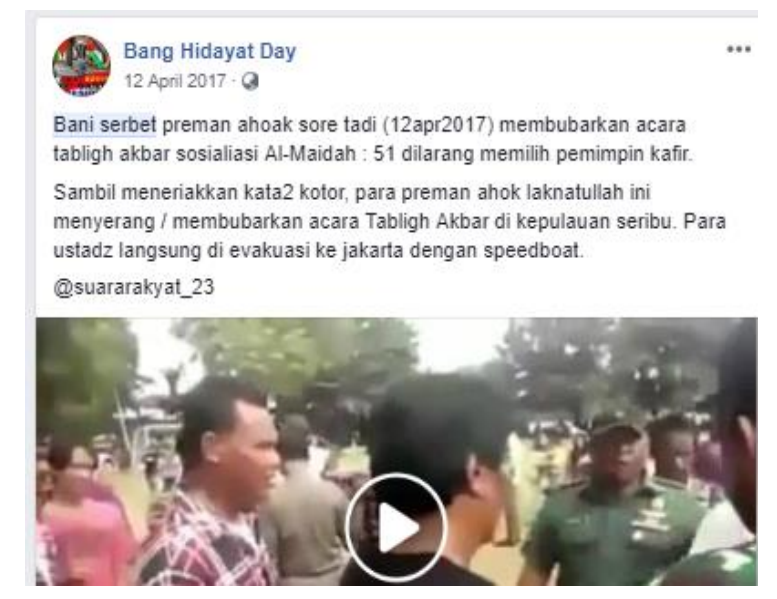

Makna dari portrait diatas adalah berupa ejekan yang sama yakni kepada pecinta atau pendukung baju kotak -kotak, karena baju kotak-kota dianggap mirip serbet.

e) Kaum Bani Cabul (Sebanyak 24.700 result sejak tahun 2017) 
Gung Joyo membagikan kiriman ke grup: MEDIA POLITIK $\quad$... INDONESIA.

29 Juli $2017 \cdot 9$

Dana haji di maling...kaum bani cabul otak sumbu pendek penghuni bumi datar kok pade diem.. sekarang dana mau dipake investasi utk kebaikan umat kok malah nyinyir.. situ waras????

Interpretasi dari status user facebook diatas adalah bahwa kaum bani cabul memiliki makna ejekan kepada pendukung Habib Riziek yang sempat terjerat kasus chat mesum dengan Fierza Husien.

f) Bani Onta (Sebanyak 57.600 result sejak tahun 2017)

Gembronk Gembrong

$\cdots$

24 Juli pukul $12.24 \cdot$ a

Ane menganggap muslim kelas coro gak ada yg cerdas, makanya ane males debat sama mereka, ngeyel meski ngawur yg penting nyosor entah apa yg dibicarakan yg di bahas apa komenya apa,,

Pasti ujung2nya penjajahan belanda hahaaaa mereka benci banget sama umat kristen.

Menurut mereka kristen masuk indonesia akibat penjajahan belanda.

Begitu kira2 dalam benak pecandu kencing onta.

Mereka gak mikir motif belanda menjajah itu apa? Belanda menjajah nusantara bukan bermotif agama t... Lihat Selengkapnya

$0=085$

18 Komentar 10 Kali Dibagikan

[3 Suka

Bagikan

Bani onta ini memiliki makna ejekan untuk keturunan Arab atau bahkan Islam secara keseluruhan. Sedangkan air kencing onta adalah olok-olok karena salah satu tokoh Islam Bachtiar Nasir pernah meminum air kencing onta dan dianggap sebagai obat.

g) Bani Cebong (Mencapai 38.300 result sejak tahun 2017) 
ARTIKEL

\section{Eka 'Alaikasalam}

17 Desember 2017 - Q

Tumben kaum bani CEBONG kaga ada yg protes dengan LGBT?

Apa jangan2 mereka bagian dari pelaku LGBT..!!!

Ini sudah jelas melanggar HUKUM agama..

Giliran ada suara khilafah aja dia pada kejang2.???

Intoleran katanya..

Di biang anti kebhinekaan lah.

Di bilang anti NKRI lah.

Di bilang melanggar UU45 lah.

Sudah hilang akal sehat nya.

Otak nya sudah terkontaminasi oleh.

LIBERAL. SEKULER.

7. Suwanto Suwanto membagikan kiriman.

21 Juli pukul $14.15 \cdot a$

Kalo pelakunya kaum Bani Cebong pasti Ga dibilang teroris, Lain kalo

pelakunya Umat Muslim pasti seluruh stasiun TV bilang ini

TERORIS...Pertanyaannya,ADILKAH INI...!

Wahai para pejabat para Aparat,bisakah kalian Usut tuntas Kasus

Ini,Sanggupkah Kalian,mampukah kalian..!!

Kurasa kalian ga bakalan bisa \& ga bakalan sanggup,soal kasus penyiram

aer keras saja kalian bagaikan macan Ompong apalagi yg ini...ku yakin \&

ku jamin kalian ga akan pernah sanggup sampai Kapanpun...!!

\#HukumYgTajamKebawahTapiTumpulKeAtas

Adapun bani cebong apabila menginterpretasi status dibawah ini adalah sebuah olok-olok atau ejekan untuk pendukung Joko widodo. Itu adalah plesetan dari Jokodok yang punya kebiasaan memelihara kodok. Cebong adalah anak kodok yang masih dalam tahap larva.

h) Bani Kampret (Sebanyak 10.200 result sejak tahun 2017 
ARTIKEL

Sinaga Irwan $>$ SAHABAT GUS DUR

17 Januari - 9

Sehebat apapun para bani KAMPRET dan Bani daster menyembunyikan aksi Wiro sableng nya...yang sok religius itu...

Eehhh akhirnya kebongkar juga kedok nya.

Q

\#banydastersoplak

\#212micincyber

\#palak40m

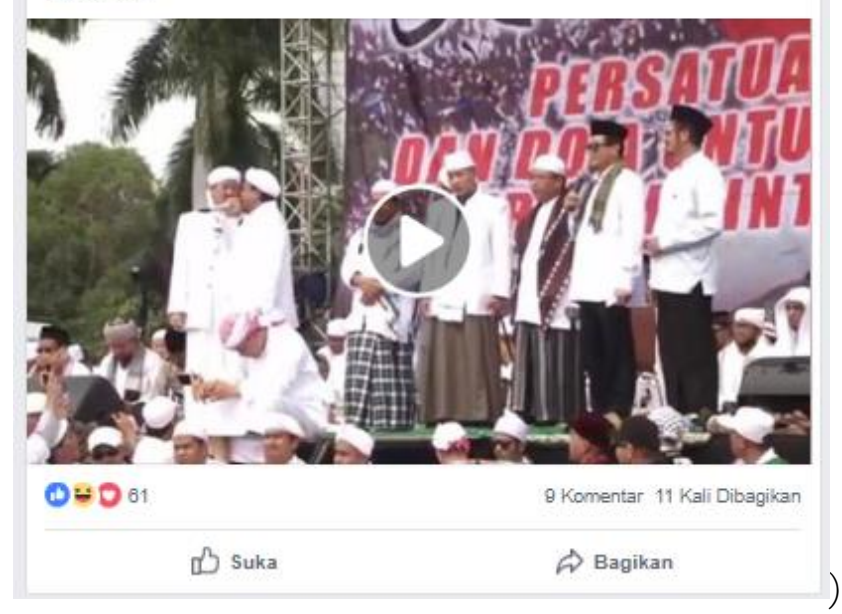

Bani kampret ini memiliki makna ejekan kepada kelompok pendukung Prabowo sebagai oposisi pemerintah. Saat pilkada lalu, Prabowo mendirikan Koalisi Merah Putuh (KMP) atau Ka-Em-Pe yang kemudian diplesetkan jadi 'Kampret'

i) Bani Micin (Sebanyak 7.000 result sejak tahun 2016)

Bboyke Aveantoo
Bani Micin !!
Manaaaa niih Bani Miciiin ??
Kalau mau demo 212 kabarin yaaah
Saya ikutan !!
Masa penipu atas nama Agama dibiarin sih ...
Atau ini enggak termasuk menista Agama ??
Situ waraaas gak seeeh ...

Pada status tersebut, bani micin memiliki makna bahwa kelompok yang disematkan dengan istilah ini adalah mereka yang bodoh karena terlalu banyak mengonsumsi micin. Micin atau MSG dianggap sebagai penyedap rasa yang bisa buat otak bodoh.

j) Bani Daster (Mencapai 5.800 result sejak tahun 2016) 
ARTIKEL

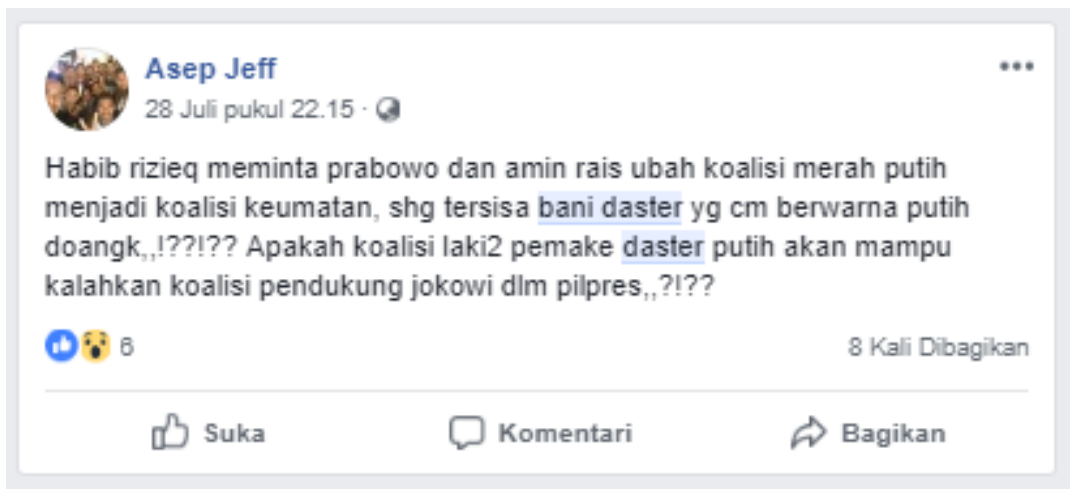

Sebagaimana yang terdapat pada tangkapan kamera diatas, bani daster ini ditujukan untuk mengejek kelompok yang biasa memakai jubah. Kelompok Islam di Indonesia, banyak yang menggunakan jubah putih dan sebagian besar adalah pria. Jubah tersebut di Indonesia mirip dengan pakaian wanita yang disebut dengan daster. Dari analisa pada teks orang-orang yang memposting istilah hujatan diatas, peneliti menemukan bahwa sebagian besar memiliki sentimen agama sehingga masuk dalam kategori intoleransi beragama. Apalagi ada beberapa penggunaan seperti 'bani' 'kaum', dll, itu jelas merujuk pada agama. Namun tidak semuanya hujatan itu ditujukan kepada umat Islam, adapula timbal balik sehingga terjadi fenomena saling hujat.

Dari 10 istilah hujatan yang ada, 7 diantaranya dijulukan kepada kelompok muslim. Sedangkan balasan julukan istilah ke non muslim yang menyerangnya hanya 3 saja. dalam hal ini dapat diketahui bahwa muslim menjadi korban dari aktivitas intoleransi tersebut di media digital, khususnya media social facebook. Disamping itu, masih banyak juga julukan lainnya. Dari 10 istilah yang dianalisa, peneliti bisa menunjukan sentimen agama atau kelompok sebagai berikut;

\begin{tabular}{|c|c|c|c|c|}
\hline \multirow[b]{2}{*}{ No } & \multirow{2}{*}{ ISTILAH HUJATAN } & \multicolumn{3}{|c|}{ GAMBARAN IDEOLOGI } \\
\hline & & Politik & Tokoh Dukungan & Pemikiran \\
\hline 1 & Kaum Bumi Datar & Oposisi & Prabowo & Fanatisme \\
\hline 2 & Kaum Sumbu Pendek & Oposisi & Riziek & Dogmatis \\
\hline 3 & Kaum Bani Taplak & Pro Pemerintah & Ahok/Jokowi & Liberal/Sekuler \\
\hline 4 & Kaum Bani Serbet & Pro Pemerintah & Ahok/Jokowi & Liberal/Sekuler \\
\hline 5 & Kaum Bani Cabul & Oposisi & Riziek & Dogmatis \\
\hline 6 & Kaum Bani Onta/Air Kencing Onta & Oposisi & Riziek & Dogmatis \\
\hline 7 & Bani Cebong & Pro Pemerintah & Jokowi & Liberal/Sekuler \\
\hline 8 & Bani Kampret & Oposisi & Prabowo & Akal Sehat \\
\hline 9 & Bani Micin & Oposisi & \# & Dogmatis \\
\hline 10 & Bani Daster & Oposisi & Riziek & Dogmatis \\
\hline
\end{tabular}




\section{Ideologi Dibalik Penggunaan Istilah Hujatan}

Selain dilakukan analisa makna, lebih lanjut peneliti juga melakukan analisa lain yakni membongkar ideologi para pengguna facebook yang menggunakan beberapa istilah tersebut. Analisa dilakukan dengan menggunakan AWK untuk membongkar ideologi yakni konteks, luaran teks, retorika, isi dan pernyataan ideologis, kekhasan dan posisi wacana. Dari hasil analisa tersebut, peneliti menemukan beberapa hasil penelitian yang berhubungan erat dengan adanya peran ideologi yang hendak mau dibangun oleh para pengguna facebook dengan menyematkan istilah-istilah hujatan tersebut. Artinya para pengguna memiliki keyakinan dan kepercayaan bahkan fanatisme khusus yang melatarbelakangi mereka menggunakan istilah tersebut .

Dari analisa konteks, peneliti menemukan beberapa hal diantaranya status yang diposting itu membahas tema hangat. Kemudian dari luaran teks, banyak diantara postingan facebook yang menggunakan judul, lampiran image dan video. Lalu dari segi retorika, para pengguna facebook menggunakan istilah itu dengan argumen-argumen tertentu hanya saja sebagian besar argumen tersebut dibangun atas dasar fanatisme atau kebencian terlebih dahulu. kemudian untuk isi dan pernyataan ideologis, sebagian besar dari pengguna yang memposting status facebook dengan istilah hujatan tersebut menggambarkan kelompok yang dijuluki dengan istilah itu sebagai pihak yang punya citra buruk. Kemudian, pesan utama dari pesan -pesan tersebut sebagian besar ditemukan adanya keberpihakan politik yang melatarbelakanginya, bukan atas dasar agama.

\begin{tabular}{c:llll}
\hline N0 & \multicolumn{3}{|c}{ ISTILAH HUJATAN } & \multicolumn{3}{c}{ Palitik } & \multicolumn{1}{c}{ Tokoh Dukungan } & \multicolumn{1}{c}{ Pemikiran } \\
\hline 1 & Kaum Bumi Datar & Oposisi & Prabowo & Fanatisme \\
\hline 2 & Kaum Sumbu Pendek & Oposisi & Riziek & Dogmatis \\
\hline 3 & Kaum Bani Taplak & Pro Pemerintah & Ahok/Jokowi & Liberal/Sekuler \\
\hline 4 & Kaum Bani Serbet & Pro Pemerintah & Ahok/Jokowi & Liberal/Sekuler \\
\hline 5 & Kaum Bani Cabul & Oposisi & Riziek & Dogmatis \\
\hline 6 & Kaum Bani Onta/Air Kencing Onta & Oposisi & Riziek & Dogmatis \\
\hline 7 & Bani Cebong & Pro Pemerintah & Jokowi & Liberal/Sekuler \\
\hline 8 & Bani Kampret & Oposisi & Prabowo & Akal Sehat \\
\hline 9 & Bani Micin & Oposisi & \# & Dogmatis \\
\hline 10 & Bani Daster & Oposisi & Riziek & Dogmatis
\end{tabular}


Detail diatas merupakan gambaran ideologi dari kelompok yang disematkan istilah-istilah hujatan tersebut. Diketahui bahwa kriteria ideologi mereka adalah sebagaimana dijelaskan dalam diagram yang ada diatas. Sementara itu untuk motif lain yang menyebabkan banyak orang menggunakan istilah hujatan yang dimaksud diatas ada beberapa alasan tertentu. Beberapa diantaranya dapat diketahui sebagai berikut:

1. Kelompok 1 (Kelompok Non Muslim)

Ini adalah kelompok yang diketahui sering menggunakan istilah hujatan yang merujuk pada kelompok muslim. Ada banyak istilah hujatan yang dibuat dan diposting di media sosial diantaranya ada sumbu pendek, bani onta, bumi datar, bani micin, bani daster dan lainnya. Sebetulnya diketahui bahwa motif mereka adalah sebagai berikut:

a. Balas dendam karena Ahok kalah dalam Pilkada

b. Tidak suka jika dalam politik membawa -bawa agama

c. Tidak suka jika ada yang menghina atau mengkritik presiden Jokowi

2. Kelompok kedua (Kelompok muslim)

Ini adalah kelompok muslim yang sering menjadi korban akan hujatan tersebut. Mereka kemudian tidak tahan lagi dan kemudian membalas dengan hujatan yang sama-sama merendahkan. Beberapa diantaranya menggunakan istilah bani cebong, bani kampret, bani taplak, dan lain sebagainya. Hal itu dilakukan atas beberapa alasan:

a. Ideologi agama bahwa memilih pemimpin harus dari muslim

b. Tidak suka jika ulama-ulamanya dikriminalisasi

c. Tidak suka dengan kebijakan-kebijakan Jokowi

d. Tidak suka pendukung Jokowi terlalu memuja kinerjanya yang tidaklah sempurna. 


\section{Kesimpulan}

Dari hasil deksripsi, pengumpulan, kategorisasi dan analisa data yang dilakukan, kemudian peneliti bisa menyimpulkan bahwa betul adanya bahwa fenomena saling hujat di media sosial khususnya facebook sudah mengarah pada fenomena intoleransi. Hal itu dibuktikan dengan banyaknya postingan hujatan yang memiliki sentimen agama. Ada banyak sekali istilah-istilah hujatan yang digunakan oleh para netizen di media digital seperti facebook. Akan tetapi peneliti membatasi pada 10 istilah hujatan saja yang diantaranya adalah kaum bumi datar, kaum sumbu pendek, kaum bani taplak, kaum bani serbet, kaum bani cebong, kaum bani kampret, kaum bani cabul, kaum bani onta, kaum bani micin dan kaum bani daster.

Kemudian istilah tersebut dianalisa dengan menggunakan teori discourse Norman Fairclough. Dari analisa makna, diketahui bahwa dari 10 istilah hujatan yang dipilih, 7 diantaranya bersentimen terhadap agama Islam, sementara 3 sisanya adalah sentimen terhadap non-muslim. Bukti bahwa ada sentimen agama, peneliti menemukan penggunaan istilah tersebut yang disertai dengan lampiran foto, link dan video yang menunjukan image agama terutama yang bersentimen pada Islam.

Sementara ideologi dari penggunaan istilah tersebut, peneliti menemukan fakta bahwa semua berawal dari ideologi politik. Kekalahan pemilukada Jakarta tahun 2016 lalu ternyata masih menyisakan dendam sampai sekarang. Pendukung Basuki Tjahja Purnama (Ahok) memiliki dukungan politik ke Joko widodo, sedangkan yang muslim mendukung Prabowo Subianto. Penggunaan istilah hujatan itu juga menyiratkan bagaimana pandangan, pola pikir, dan prinsip. Orang-orang yang menggunakan 7 istilah lebih Islami, dogmatis dan pandangan politiknya mendukung Prabowo. Sedangkan 3 lainnya itu memiliki pemahaman liberal, sekuler dan dukungan politik pada Joko Widodo.

Peneliti berharap penelitian ini bisa menyadarkan para netizen bahwa penggunaan istilah hujatan itu telah menimbulkan konflik intoleransi. Meski bentuk intoleransinya bukan berupa fisik melainkan verbal, namun bisa membahayakan negeri ini karena bisa saja pecah menjadi konflik fisik. Selain itu 
ARTIKEL

saran untuk peneliti selanjutnya diharapkan ada yang melakukan analisis lain lebih mendalam seperti dari resolusi konflik yang bisa dilakukan untuk mengatasi masalah pudarnya kerukunan beragama karena hal tersebut.

\section{DAFTAR PUSTAKA}

Armala, Rustin. Relasi Antara Agama Islam, Hindu Dan Kristen: Studi Tentang Hubungan Umat Beragama. Surabaya: UIN Sunan Ampel Surabaya, 2011.

Effendi, Djohan. Merayakan Kebebasan Beragama Bunga Rampai Menyambut 70 Tahun. Jakarta: ICRP, 2009.

Fairclough, Norman. Critical Discourse Analysis: the Critical Study of Language, New York: Longman Group Limited, 1995.

Hasan, Ruqaiya. Bahasa, Konteks, dan Teks, terjemahan Asruddin Barori Tou. Yogyakarta: Gadjah Mada University Press, 1994.

Hasyim, Umar. Toleransi dan Kemerdekaan Beragama dalam Islam Sebagai Dasar menuju Dialoq dan Kerukunan Antar Umat Beragama. Surabaya: Bina Ilmu, 1979.

Hidayati, Ratnasari. "Hakikat Toleransi Antar Umat Beragama" Malang; Universitas Brawijaya, academia.edu (diakses pada 1 Januari 2018, 13:03)

Holsti. Content Analysis for the Social Science and Humanities. Reading, Massachusetts: Addison - Westley Pub lishing, 1969.

Hosen, Nadirsyah (2005-09-08). "Religion and the Indonesian Constitution: A Recent Debate" (PDF). Journal of Southeast Asian Studies (Cambridge University Press). doi:10.1017/S0022463405000238. Diakses tanggal 201712-26.

Khotimah. "Makna Agama dan Munculnya Agama Baru" Academia.edu, PDF edition:

http://www.academia.edu/12124370/MAKNA_AGAMA_HINGGA_MU

NCULNYA_AGAMA_BARU_(diakses pada Sabtu, December 12nd, 2017)

Mulyono, Bashori. Ilmu Perbadingan Agama, Indramayu, Pustaka Sayid Sabiq, 2010.

Munandar. Ilmu Sosial Dasar. Teori \& Konsep. Bandung: ERSCO, 1987.

Mustaqim, Abdul. "Konflik Teologis Dan Kekerasan Agama Dalam Kacamata Tafsir Al-Qur'an.” Jurnal Epistemé, Volume 9, Nomor 1, Juni 2014.

Nuh, Abdullah bin. Kamus Baru. Jakarta; Pustaka Islam, Cet. 1, 1995.

Rahman, M Taufiq, Social Justice in Western and Islamic Thought: A Comparative Study of John Rawls's and Sayyid Qutb's Theories of Social Justice. Saarbruken: Germany. Scholar's Press. ISBN 978363966980, 2014. 
Rizal, Fakhri. 'Tujuan Toleransi Beragama' Jejak Pendidikan: Portal Pendidikan Indonesia via jejakpendidikan.com, (diakses 27-12- 2017, 12.32 WIB)

Rohman, Fathur. Analisis Meningkatnya Kejahatan Cyberbullying Dan Hatespeech Menggunakan Berbagai Media Sosial dan Metode Pencegahannya. Draft Seminar Nasional Ilmu Pengetahuan dan Teknologi Komputer (SNIPTEK) 2016, Nusa Mandiri University, 2016.

Schiffrin, Deborah. Ancangan Kajian Wacana. Yogyakarta: Pustaka Pelajar, 2007.

Wach, Joachim, The Comparative Study Of Religions. Colombia: University Press,. 1958 . 